\title{
Evaluation of using edible coating and ripening on Dangke, a traditional cheese of Indonesia
}

\author{
${ }^{1 *}$ Malaka, R., ${ }^{2}$ Hatta, W. and ${ }^{3}$ Baco, S. \\ ${ }^{1,2}$ Laboratory of Biotechnology of Milk Processing, Department of Animal Production Technology, \\ Faculty of Animal Husbandry, Hasanuddin University, Indonesia \\ ${ }^{3}$ Laboratory of Animal science, Faculty of Animal Husbandry, Hasanuddin University, Indonesia
}

\begin{abstract}
Article history:
Received: 7 February 2017

Received in revised form:

2 March 2017

Accepted: 3 March 2017

Available Online:

10 March 2017
\end{abstract}

Keywords:

Dangke

Soft cheese

Edible coating

Physical properties

DOI:

http://doi.org/10.26656/ fr.2017.2.006

\begin{abstract}
Dangke is a traditional soft cheese from Enrekang, South Sulawesi Indonesia which is produced through heat denaturation at $85^{\circ} \mathrm{C}$ and enzymatic coagulation using papaya latex. The quality, microstructure and storage life of the cheese are affected by several factors such as denaturation temperature, enzyme concentration, moulding pressure, coating, and ripening. The objective of this study was to evaluated of using edible coating and ripening on Dangke cheese. The experiment was conducting using factorial design with five replications. The experimental variables were the type of edible coating used (agar, CMC and bee wax) and the length of ripening (10, 20 and 30 days). Parameter was measured hardness, microstructure, and sensory evaluation. The overall result indicated that the use of edible coating can extend the shelf life, increase hardness, and more compact microstructure. Sensory evaluation also indicated that the cheese coated with film forming edible materials had had white color, more milk like smell (smelly milk), and smoother texture.
\end{abstract}

\section{Introduction}

The milk consumption in Indonesia is still very low (Sukarelawati, 2016), while in fact there is a traditional dairy product produced by the community Enrekang South Sulawesi. Therefore Dangke as traditional cheeses should be disseminated and studied aspects of the physical, chemical, microbiological and microstructure so that the production process could eventually be registered as one type of cheese that can be adopted for the industry. In Indonesia, milk and milk product mainly produced on village farms and rural area. Livestock farming in general and milk products in particular still play an important socio-economic role in developing countries (Hamid and Owni, 2007).

Dangke is a type of traditional cheese of Enrekang South Sulawesi, Indonesia, semisolid cheese as available in the traditional market and traditionally manufactured by local people (Rasbawatiet al., 2014) or community. It is prepared traditionally by heating milk in open pan and clotting using papaya extract. The coagulated curd placed in perforated coconut shells for drainage of whey and pressing the curd by spoon (Aras, 2009; Malaka, 2009; Sukmasari, 2009).

Cheese is the generic name for group of fermented milk-based food products, produced in a great range of flavors and forms throughout the world (Fox, 1993). Cheese has been defined by Davis (1976) as a product made from milk by coagulating the casein with rennet or similar enzymes in the presence of lactic acid produced by added or adventitious microorganisms, from which part of the moisture has been removed by cutting, cooking and/or pressing. According this definition so Dangke can be classified as cheese. Dangke is packed with a banana leaf and ready to be consumed or stored in refrigerator. Dangke is made mainly from fresh cow milk or buffalo milk that shelf live is generally two days at room temperature (Hatta et al., 2013). Type of the cheese is classified as fresh cheese durability at temperatures of storage space very quickly spoilage. Dangke similar with 'Dali' a traditional fresh cheese from North Tapanuli, Medan, North Sumatera, Indonesia, made from cow's and buffalo milk using the existing local process, coagulated by pineapple extract and papaya sap (Sirait, 1991). Therefore it is necessary to improve the quality by coating technology in order to reduce the contamination of bacteria from the environment. Edible coating are widely used to fruits, such as on research Licodiedoff et al. (2016) had studied on conservation of physalis by edible coating of gelatin and calcium chloride.

Dangke was product by traditional processing that cause of many bacterial contaminated. The Study can serve as a guide for the use of new 
technique to increase self-life by using coating for cheese as alternative of future new material for this purpose. Edible coating has established deliberation in modern eons because of their benefits comprising synthetic polymers materials. This could contribute to the reduction of environmental contamination (Sit and Shah, 2014). Dangke cheese just after its manufacturing is of significant commercial interest as a means of arresting physicochemical changes in cheese during ripening and to extend its self-life. In this study, the manufacture of cheese ripened using edible coating material is beeswax, Agar and CMC (carboxymethyl cellulose). This research aims to determine the ability of edible coating to increasing quality of physical properties and microstructure of Dangke during ripening.

\section{Materials and methods}

\subsection{Preparation of papaya latex and Dangke cheese manufacture}

Papaya latex was collected from papaya fruit fresh in the morning and evening then dried in oven at $45^{\circ} \mathrm{C}$ before use as coagulant. Raw bovine milk supplied from traditional dairy small holder of Enrekang Regency was used in the manufacture of Dangke cheese samples. Dangke Cheese was accomplished using whole fresh milk that pasteurized at $85^{\circ} \mathrm{C}$ for $5 \mathrm{~min}$ and added papaya extract powder (Laboratory of biotechnology of milk, Faculty of Animal Husbandry, Hasanuddin University) $0.05 \%$ $(\mathrm{v} / \mathrm{v})$ was coagulation of milk protein. These methods produced by the traditional methods but were standardized for concentration of papaya extract and pasteurization methods by our experimental (Laboratory of biotechnology of milk, Faculty of Animal Husbandry, Hasanuddin University).

Table 1. Ingredients and formula used to prepare Dangke cheese.

\begin{tabular}{lc}
\hline \multicolumn{1}{c}{ Ingredient } & Quantity (\%wt/wt) \\
\hline Whole fresh milk & $98.5 \%$ \\
Salt & $1 \%$ \\
Extract of Papaya Sap & $0.05 \%$ \\
\hline
\end{tabular}

The coagulated milk was poured in the coconut shell with a hole at the bottom where the whey drainage through. After the whey was removed by pressing with spoon, Dangke curd removed from coconut shell template. The first treatment was dangke curd dipped in beeswax, the second treatment was dipped into order and third treatment was dipped in the CMC. Time of soaking in each coating material is for 5 seconds on each sample. The samples were subjected for physical properties analysis for hardness and sensory evaluation and microstructure. The manufacturing, hardness and sensory analysis were repeated five times.

\subsection{Sample preparation}

A single piece of each cheese Dangke was produced for each sample of this study. There are three group i.e. Group I is Dangke coating by bee wax, Group II is Dangke coating by Agar and Group III is Dangke coating by CMC. Cheese Dangke loaves were cut into $5 \times 5 \times 5 \mathrm{~cm}$ block, sealed in plastic cheese packing bags and stored in refrigerator at $5^{\circ} \mathrm{C}$ for 30 days.

\subsection{Hardness}

The Hardness of Dangke cheese measurement was use CD-Shear Force (Equipment produced and standardized by Laboratory of Production of Animal Husbandry, Hasanuddin University). The data was analyzed by equation as:

Hardness $\left(\mathrm{kg} / \mathrm{cm}^{2}\right)=\frac{A}{L}$, where A=Loading stress; $\mathrm{L}=$ sectional area of sample, $\pi=3.14 ; \mathrm{r}=$ radius of sample $(0,635)$.

\subsection{Sensory evaluation}

The product was evaluated by conducting sensory evaluation of panel of 30 semi-trained judges. The flavor (1-5), body and texture (1-5), color and appearance (1-5), modification according by Gaikwad and Hembade (2011), Kanombirira and Kailasapathy (1995), used sensory spectrum descriptive analysis (Meilgaard et al., 1999), the higher number indicating greater intensities. The panel received 15 sessions. During the sessions the panelists defined flavor, body and texture, color and appearance term and were trained about the appropriate techniques for evaluating the samples and in the use of reference scales. A two-way analysis of variance (ANOVA) was used to test the sensory score data. Differences among the means were compared using Duncan's Multiple Range Test.

\subsection{Microstructure}

Microscopic analysis of acid coagulated fresh cheese was carried out by some modification of techniques of Malaka (1997). Dangke cheese samples approximately three $\mathrm{mm}$ cubes were fixed in $5 \%$ glutaraldehyde solution for $24 \mathrm{~h}$ and dehydrated in a series of ethanol-distilled water solution (60, $70,80,90$ and $100 \%(v / v)$ ethanol). Sample was cut by microtome knife and fixated in object glass then dyed by hematoxylin Eosin, and then view the 
microstructure by light microscopic magnification 1000 (objective 100 and ocular 10).

\section{Results}

\section{Hardness}

Figure 1 shows the average of Dangke hardness after ripening until 30 days at refrigerator and evaluated the value each 10 days. Random analysis indicated that the different until 30 days ripening shows significant result on Dangke Hardness, but by Agar Coating indicated the best result $\left(61.3 \mathrm{~kg} / \mathrm{cm}^{2}\right)$. This kind of traditional cheese tended to become compact with progress of ripening. The hardness was increased by increasing of time ripening, indicated that hardness of all processed cheese were influenced by duration of ripening.

\section{Hardness $(\mathrm{kg} / \mathrm{cm} 2)$}

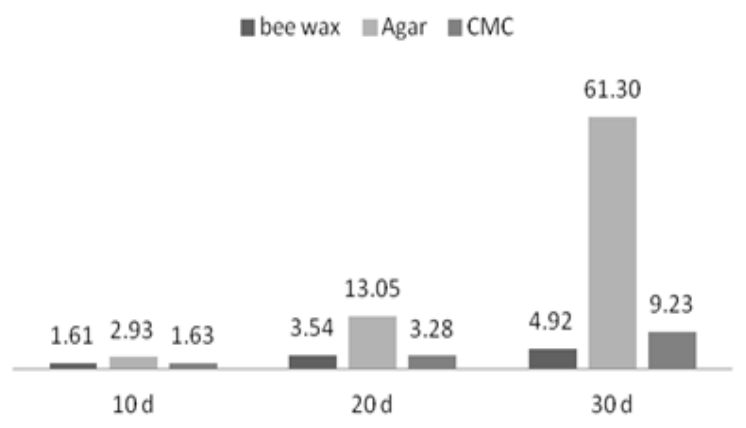

Figure 1. Hardness of Dangke Cheese by different of coating and long life ripening

\section{Sensory evaluation}

The results of sensory evaluation of Dangke samples are shown in Table 2. The ripening time and edible coating were not significantly $(\mathrm{P}>0.01)$ affected with edible coating type hence panelists have given of score, but were significantly affected on flavor of Dangke. The product made with all processing due to color of Dangke product same with milk color (white color). Slight variation was observed in color scores of all dangke cheese samples but by statistical analysis not significance.

Table 2.The effect of edible coatings on the sensory qualities of Dangke.

\begin{tabular}{lccccc}
\hline Attributes & Bee wax & CMC & Agar & SD & SE \\
\hline Flavor & 3.17 & 3.87 & 3.67 & 0.343 & 0.094 \\
$\begin{array}{l}\text { Body and texture } \\
\begin{array}{l}\text { Color and } \\
\text { appearance }\end{array}\end{array}$ & 3.43 & 3.27 & 3.47 & 0.094 & 0.067 \\
\hline
\end{tabular}

Note: Score : $1=$ not good $-5=$ very good $\mathrm{SD}=$ standard deviation; $\mathrm{SE}=$ Standard Error

\section{Microstructure of Dangke}

During the press the curd in the coconut shell with a hole at the bottom as a template form of cheese Dangke (traditional template), the protein form into fibers in a roughly parallel manner as shown in Figure 3 . Consequently, fat and water accumulate between the long strands of protein. The microstructures of cross-sectionally samples were different between one edible coating and another edible coating. The microstructure of uncoating Dangke at 10 days after manufacture, there were a large number irregular cavities dispersed randomly throughout the protein matrix.

\section{Discussion}

Cerqueira et al. (2009) studied the functional polysaccharide as edible coating for cheese i.e chitosan, galactomannan and agar and corn oil. The result of studies indicated that the surface properties of the cheese and the wetting capacity of the coating on the cheese were determined. The uncoated cheese had an extensive mold growth at the surface when compared with the coated cheese. The results show that these coating can be applied as an alternative to natural coating. According to this results indicated that another natural polysaccharide can be used for Dangke cheese coating. Furthermore from the results of my study from evaluated hardness and microstructure showed that the best of coating was bee wax.

Hydrocolloids are often hydrophilic polymers, of vegetable, animal, microbial, or synthetic origin, that generally contain many hydroxyl groups (polysaccharides) and may be polyelectrolytes. Agar was a group a plant-derived polysaccharides that appear to work well with low moisture foods but was for moisture barrier (Shit and Shah, 2014).

\section{Hardness}

Physical properties of cheese, in particular hardness, depend on moisture content. Many processing factors affect the structure and, therefore, the texture and rheology of cheese (Guinee et al., 1993), included Dangke as an Indonesia soft cheese. The hardness indicated that strengthen of molecule interaction within composition of milk. Hydrophobic interaction increase with increasing time of ripening, causes the casein molecules to contract, as a result, the stiffness of milk gel network is reduced (Lucey et al., 2003). Some of the weakening of gels with increasing temperature could also be due to the decrease in strength of hydrogen bonds (Bryant and McClements, 1998). The hardnees characteristics 
close with the microstructure. Coating of Dangke cheese results in proteins (mainly casein) becoming absorbed at the newly created by polysaccharides interface interaction (Agar, CMC and bee wax).

Characteristics of hardness are closely related to microstructure. Cheese Dangke structure becomes more compact due to the interaction between fat, protein and water to form a three-dimensional network. Using Agar as a coating seen that Agar is absorbed and interact with curd dangke so that the product looks wet, so similar when using CMC. But the use of beeswax, visible layer to dry more quickly and are not sticky, so the structure dangke better, because the coating material and the curds was seen separate.

\section{Sensory evaluation}

Consumer acceptance of a cheese product depends directly on its appearance and flavor and texture which are in turn originated by a thorough combination of microbiological, biochemical and technological parameters, that affect microstructure directly and indirectly (Pereire et al., 2009). Human perceptions of organoleptic characteristics are closer to the consumers' status of the moment of decision than data generated by any type of analytical instrumentation (Adhikari et al., 2003).

The body and texture of Dangke after ripening to 30 days similarly with Mozzarella cheese that uniform, smooth and meaty (not too firm or too soft and pasty) (Mijan et al., 2010). The Dangke cheese was made from cow milk, generally had appearance, smooth surface, free from cracks and practically free from moulds. Texture is intrinsically related to the arrangement of various chemical components within distinct micro- and macrostructure levels e.g. protein network or fat fraction; it is the external manifestation of such structures that eventually determines the uniqueness and distinctive character of a cheese product (Pereira et al., 2009). The Dangke color made by coating Bee wax, CMC or Agar was similarly are yellowish-white and white, the difference might be due to carotene in milk.

\section{Microstructure of Dangke}

Structure of cheese at a micron scale, can determine consistency and yield. Microstructure influences functional properties such as texture, shredability, melting, stretching, and link to rheological, textural and chemical analysis to determine structure-function relationships. Microstructure is not a static concept; it evolves instead along the food processing chain, and eventually leads to major transformation relative to the original microstructure of the milk feedstock itself. This realization thus encompasses specific molecular composition and spatial arrangements (Pereira et al., 2009). During the ripening process of Dangke at $5^{\circ} \mathrm{C}$, then Dangke have a process of fermentation by lactic acid bacteria which are naturally present in milk. From a fermentation point of view lactose is the most important constituent of milk, which is in solution in the milk composed of one molecule the isomers $\alpha$ or $\beta$-glucose linked to one molecule of $\beta$-galactose. Lactose hydrolysis can be take place due to enzymatic reaction which is particularly important in the cheese making process. In the natural ripening the action of bacteria ferment the lactose to lactic acid, at the same time, may be responsible for the production of other substance such as acetylmethyl-carbinol and siacetyl which are responsible for flavor production. These causes the longer of ripening can increase the hardness of Dangke cheese.
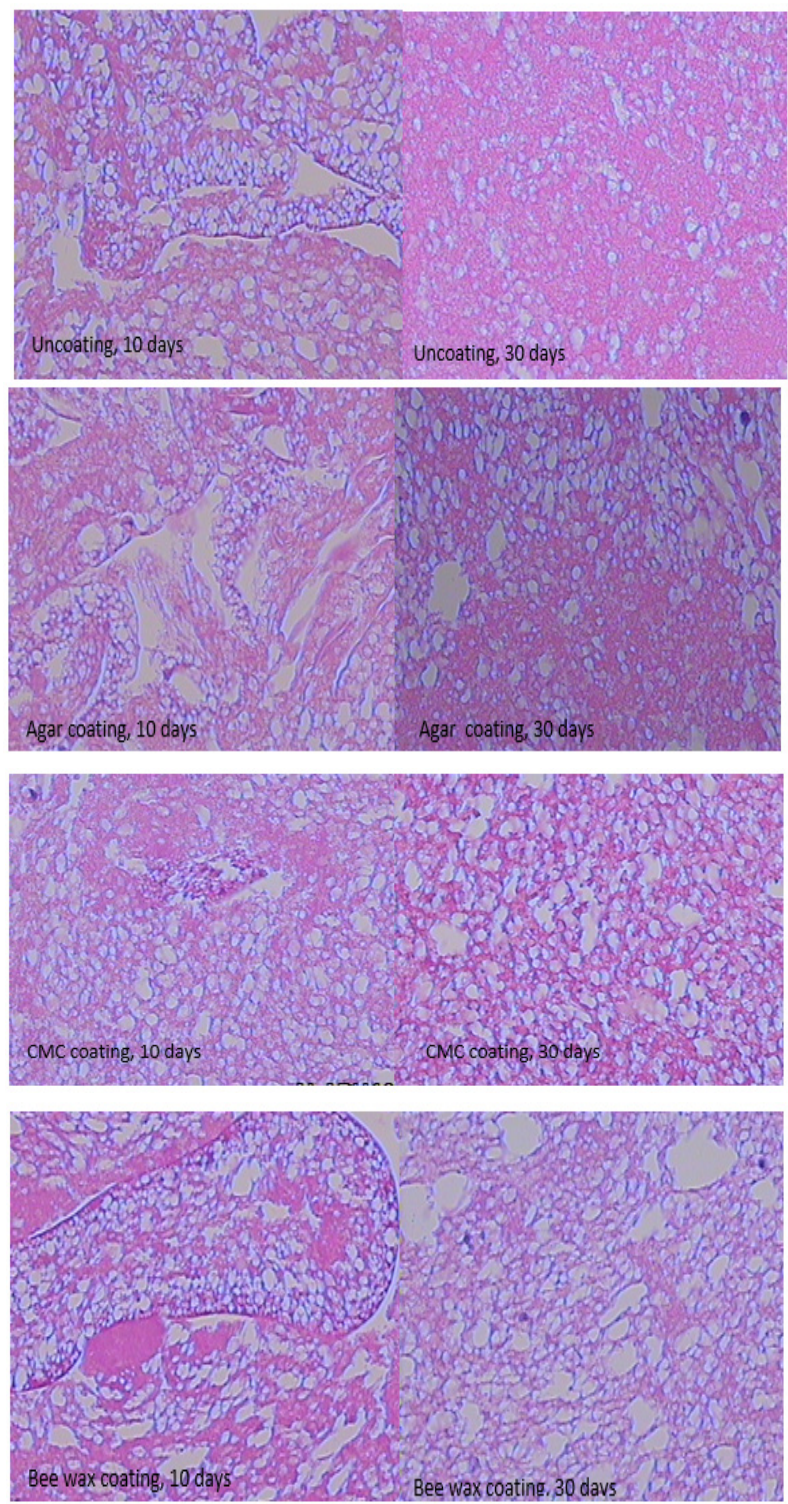

Figure 2. Microstructure of Dangke cheese by different edible coating at 10 and 30 days ripening 
During the press the curd in the coconut shell with a hole at the bottom as a template form of cheese Dangke (traditional template), the protein form into fibers in a roughly parallel manner as shown in Figure 2. Consequently, fat and water accumulate between the long strands of protein. The microstructure of cross-sectionally samples was different between Dangke with Agar coating and Beeswax, CMC and Beewax but similar between the CMC and Agar. The microstructure of uncoating Dangke at 10 days after manufacture, there were a large number irregular cavities dispersed randomly throughout the protein matrix. Some of these cavities may represent the site originally occupied by the extracted fat, and some were originally occupied by whey (Kuo and Gunasekaran, 2009). Microstructure technique show insight into how fat may be lost during processing link between microstructure and texture properties.

The structure of cavities and protein matrix continued to change through 30 days post manufacture, thin strands of protein material encroached from all sides, connected the cavity walls that the spherical shape of fat globules were distinctly defined, but position of the fat globules does not change during aging. The water originally at the irregular cavities, so in the microstructure of Dangke appears to become absorbed into the protein matrix during the early stage of maturation. This was accompanied by a swelling of the protein matrix that continued until the spaces between the fat globules were completely filled with protein matrix as evidenced by the formation of reticular structure. Cheese is particularly complex systems, so full and meaningful assessment of the effects of microstructure and texture upon flavor and appearance is still incipient.

The differences between the milk species (casein) in fat globules size are best appreciated by comparisons of the actual frequency distributions rather than by calculated average (El-Zeini, 2006). The structure of fat globules showed as imperfect spheres which could have length and width as imperfect rectangles. For all milk species, the average volume was the highest for buffalo milk fat globules $\left(344.9 \mu \mathrm{m}^{2}\right)$; cow $\left(32.28 \mu \mathrm{m}^{2}\right)$; Sheep $(28.29$ $\left.\mu \mathrm{m}^{2}\right)$; goat $\left(18.65 \mu \mathrm{m}^{2}\right)$ and camel $\left(13.99 \mu \mathrm{m}^{2}\right)$ (ElZeini, 2006). Result indicated that fat globules pool together at higher protein concentration and the fat distribution was more heterogeneous. Changes in protein network structure affect cheese texture.

Dangke cheese quality can increase by enhance cheese-dangke-making which stipulated the concentration of papaya wax will be add and the ripening time. Dangke uncoated seen that at 10 days storage appear to have a microstructure was not compact, still a lot of water in the curd, but after 30 days storage of the microstructure of cheese looks more compact and water content was decreasing. The use of edible coatings can improve the quality of the Dangke cheese with increasing ripening time. This is indicated by the Dangke increase the hardness, and shows the microstructure more compact, furthermore panelist evaluated that Dangke was white color, smelly milk, and smooth texture. There is indicated that is correlation between the hardness and microstructure of Dangke cheese.

\section{Conflict of interest}

This article has no conflict of interest with any party or case.

\section{Acknowledgments}

Authors gratefully acknowledge the financial assistance receiver from Ministry of Education and Research and Technology and Hasanuddin University, Indonesia.

\section{References}

Adhikari, K., Heymann, H. and Huff, H.E. (2003). Textural characteristics of lowfat, full fat and smoked cheeses, sensory and instrumental approaches. Food Quality and Preference, 14, 211-218.

Aras,W. (2009). Effect of crude papain levels and heating temperatures on Dangke Quality. Thesis. Faculty of Animal Husbandry, Hasanuddin University.

Bryant, C.M. and McClements, D.J. (1998). Molecular basis of protein functionality with special consideration of cold-set gels derived from heat-denaturated whey. Trends Food Science and Technology, 9,143-151.

Cerqueira, M.A., Lima, A.M., Souza, B.W.S., Teixeira, J.A., Moreira, R.A. and Vicente, V.C. (2009). Functional polysaccharides as edible coating for cheese. Journal of Agriculture and Food Chemistry, 57(4), 1456-1462.

Davis, J.G. (1976). Cheese.J and A Churchill Ltd, London, UK.

El-Zeini, H.M. (2006). Microstructure, Rheological and Geometrical Properties of fat globules of milk from different animal species. Polish Journal of Food and Nutrition Sciences, 15(56/2), 147-154.

Fox, P.F. (1993). Cheese: An overview. In.P.F. Fox. (Eds), Cheese: Chemistry, Physics and Microbiology, p. 1-36. Chapman and Hall. London.

Gaikwad, S.M. and Hembade, A.S. (2011). Standardization and Production of traditional Indian Milk product 'Ujanibasundi' from Buffalo milk. International Journal of Livestock Production, 2(8), 129-133. 
Guinee, T.P., Pudja, P.D. and Farkye, N.Y. (1993). Fresh acid curd cheese varieties. Pages 363-419 in cheese, chemistry, physics and Microbiology, Vol. 1, 2nded. F.F.Fox ed. Chapman and Hall. London. UK.

Hamid, O.I.A. and El Owni, O.A.O. (2007). Microbiological properties and sensory characteristics of white cheese (Gibnabayda) collected in Zalingei Area, West Darfur State. Research Journal of Animal and Veterinary Sciences, 2, 61-65.

Hatta, W., Sudarwanto, M., Sudirman, I. and Malaka, R.(2013). Prevalence and sources of contamination of Escherichia coli and Salmonella spp. in cow milk dangke, Indonesian Fresh Soft Cheese. Global Veterinaria, 11(3), 352-356.

Kanombirira, S. and Kailasapathy, K. (1995).Effect of interaction of carrageenan and gellan gum on yields, textural and sensory attributes of Ceddar cheese. Milchwissenshaft, 50(8), 452-457.

Kuo, M.I. and Gunasekaran, S. (2009). Effect of freezing and frozen storage on microstructure of Mozzarella cheeses. LWT Food Science and Technology, 42, 9-16.

Licodiedoff, S., Koslowski, L.A.P., Scartizzini, L., Monteiro, A.R., Ninow, J.L. and Boges, C.D. (2016). Concervation of physalis by edible coating of gelatin and calcium chloride. International Food Research Journal, 23(4), 1629-1634.

Lucey, J.A., Johnson, M.E, and Horne, D.S. (2003). Perspectives on the basis of the rheology and texture properties of cheese. Journal of Dairy Science, 86, 2725-2743.

Malaka, R. (2009). Mechanism of Gelation of Markisa Cheese by Physical Properties and Microstructure analysis. Paper of Seminar National Faculty of Animal Husbandry Padjadjaran University. Yokyakarta.

Malaka, R. (1997). Effect of Curdlan, a bacterial Exopolysaccharide on rheological properties and microstructure of acid milk curd by lactic acid fermentation. Thesis, Miyazaki University. Japan.

Meilgaard, M., Civille, J.V. and Carr, B.T. (1999). Sensory evaluation techniques, 3rd ed. CRC Press, Boca Raton, F.L.

Mijan, M.A., Haque, M.A. and Wadud, M.A. (2010). Evaluation of quality of Mozzarella cheese. The Bangladesh Veterinarian, 27(1), 36-42.

Pereire, I.P, Gomes, A.M.P. and Malcata, F.X. (2009). Microstructure of cheese: processing, technological and microbiological considerations. Trends in Food Science and Technology, 20(5), 213-219.

Rasbawaty, B. Dwiloka, A.N. Albaarri, A.M. Legowo, V.P. Bintoro. (2014). Total bacteria and $\mathrm{pH}$ of Dangke preserved using natural antibacterial lactoferrin and lactoferoxidase from bovine whey. International Journal of Dairy Science, 9(4), 116-123.

Sit, S.C. and P.M. Shah. (2014). Edible Polymers: Challenges and Opportunities. Journal of Polymers, 2014: p. 13. http://dx.doi.org/10.1155/2014/427259.

Sirait, C.H. (1991). Evaluasi produk dali di daerah Porsea-Sumatera Utara. Proceeding Seminar Nasional "Usaha Peningkatan Produktivitas Peternakan dan Perikanan”. Universitas Diponegoro. Semarang.
Sukarelawati, E. (2016). Konsumsi Susu Masyarakat Indonesia Masih Rendah. Copyright(CAntara 2016. Antara news.com.

Sukmasari, D. (2009). Effect of Ripening by Lactococcuslactis ssp. lactis 527 on Dangke Quality. Skripsi. Hasanuddin University. 